\title{
Relationships between insect predator populations and their prey, Thrips tabaci, in onion fields grown in large-scale and small-scale cropping systems
}

\author{
Elaine J. Fok · Jessica D. Petersen • \\ Brian A. Nault
}

Received: 29 January 2014/ Accepted: 13 August 2014/Published online: 27 August 2014

(C) The Author(s) 2014. This article is published with open access at Springerlink.com

\begin{abstract}
Onion thrips, Thrips tabaci Lindeman, is the primary pest of onion, which is grown in either large-scale, monoculture systems surrounded by other onion fields, or in small-scale systems surrounded by multiple vegetable crops. In 2011 and 2012, populations of insect predators and their prey, T. tabaci, were assessed weekly in onion fields in both cropping systems. Insect predator taxa (eight species representing five families) were similar in onions grown in both systems and the most commonly occurring predators were from the family Aeolothripidae. Seasonal population dynamics of predators and T. tabaci followed similar trends within both cropping systems and tended to peak in late July and early August. Predator abundance was low in both systems, but predator abundance was nearly 2.5 to 13 times greater in onion fields in the small-scale system. T. tabaci abundance often positively predicted predator abundance in both cropping systems.
\end{abstract}

Keywords Predators - Onion thrips - Biological control · Thysanoptera - Thripidae - Allium cepa L.

Handling Editor: Arne Janssen.

E. J. Fok · J. D. Petersen · B. A. Nault ( $₫)$

Department of Entomology, Cornell University, New

York State Agricultural Experiment Station, $630 \mathrm{~W}$.

North Street, Geneva, NY 14456, USA

e-mail: ban6@cornell.edu

\section{Introduction}

Approaches selected to manage insect pests in agricultural crops are often associated with the scale of the farming operation. Crops grown on small, diversified farms rely more on cultural and naturally occurring biological control compared with crops grown in large-scale, monoculture cropping systems that rely more on chemical control (Altieri and Nicholls 2001; Tscharntke et al. 2012). Moreover, pest management choices in these two types of cropping systems may have variable indirect effects on natural enemies (Landis et al. 2000).

Onions are grown in both large-scale and smallscale cropping systems. In New York State (USA), onions grown in large-scale systems are often partitioned in $2-4$ ha fields, but these fields may be contiguous and span hundreds of hectares. In contrast, onions grown in small-scale systems are planted in fields ranging from $<0.04$ to 0.8 ha on diversified vegetable farms with multiple crops growing in adjacent fields. Small-scale systems are characterized by diversification strategies that alter the structural diversity of the crop, grow multiple varieties of one crop, allow weedy vegetation to persist, grow multiple crops within a field, leave fields fallow adjacent to crop fields, integrate agroforestry or livestock, and conserve woodlands or natural habitats surrounding the farm (Gurr et al. 2003). Another difference between the two systems is that insecticides are typically applied more frequently in large-scale 
systems than those used in small-scale systems (personal observation).

Onion thrips (Thrips tabaci Lindeman) is the most economically important insect pest of onions (Allium cepa L.) worldwide (Diaz-Montano et al. 2011) and the most damaging pest of onion in New York (Hoffmann et al. 1996). T. tabaci indirectly damages the crop by feeding and reproducing on onion leaves, with three to five overlapping generations every season (Hoffmann et al. 1996). Adults and larvae hide in leaf folds and between touching leaves, preferring to feed on the youngest leaves with their piercing-sucking mouthparts (Kirk 1997a; Mound 2005). T. tabaci feeding causes leaf necrosis, which reduces photosynthetic ability and consequently bulb size and weight, reducing bulb yield by up to $40 \%$ (Fournier et al. 1995).

Conventional control of $T$. tabaci has relied on multiple applications of insecticides (Shelton et al. 2006; Nault and Shelton 2010). Recently, novel selective insecticides co-applied with penetrating surfactants have been shown to improve T. tabaci control (Nault et al. 2013) and reduce the number of applications needed to protect the crop during the season (Nault and Shelton 2010). Anecdotally, there have been reports of more predatory insects observed in onion fields since these management changes have been adopted (personal observation). However, the species identity and abundance of predators in onion cropping systems in New York are not known.

The objectives of this research were to (1) identify insect predators of T. tabaci and their abundance in the two types of onion production systems in New York, (2) describe the temporal patterns of the predator and T. tabaci populations in these onion fields, and (3) explore to what extent predator abundance can be predicted by $T$. tabaci abundance within the two onion production systems. Information generated from this research will provide insight into the abundance of $T$. tabaci and their predators in these two types of onion production systems.

\section{Materials and methods}

Site description and experimental design

Research was conducted in major onion-producing regions in central and western New York in 2011 and
2012. Onion production systems were classified as either a large-scale or small-scale cropping system. Large-scale systems included onion fields that were part of a contiguous series of onion fields ranging from 40 to over 1,000 ha and surrounded by woods, whereas small-scale systems included a single onion field $<2$ ha surrounded by other vegetable crops such as cabbage, lettuce, potato, squash and sweet corn. Barley (Hordeum vulgare L.) was co-planted alongside onion in large-scale cropping systems because barley germinates more quickly than onion and protects onion seedlings by serving as a mini windbreak. Following onion establishment in mid to late May, barley is killed immediately using selective herbicides. Weeds were uncommon within onion fields in large-scale cropping systems and more common in fields in small-scale systems. Small-scale systems met one or more diversification strategies designed to enhance biological control and benefit pest management (Gurr et al. 2003).

Insecticides used in large-scale cropping systems were applied more frequently than those used in small-scale systems. Abamectin, methomyl, spirotetramat and spinetoram were used in large-scale onion fields, while spinosad and various organic oils were used in small-scale fields. All onion fields in this study were grown according to commercial onion production guidelines for New York (Reiners and Petzoldt 2014).

Large-scale and small-scale systems were separated by a minimum of $6 \mathrm{~km}$ and onion fields sampled within a system were separated from each other by at least $0.1 \mathrm{~km}$. In 2011, four large-scale and four smallscale fields were sampled for a total of eight fields. In 2012, six large-scale and six small-scale fields were sampled for a total of 12 fields. Insecticide-free plots were also established along one edge of each onion field.

\section{Grower-managed onion fields}

Dry bulb onion fields were transplanted from April through May each year. The size of onion fields in large-scale systems were $2-4$ ha and those in smallscale fields were $<0.04$ to 0.8 ha. No modifications were made to planting, management, or harvest practices in these onion fields, thus, we considered these to be "grower-managed". 


\section{Insecticide-free onion plots}

Onions, var. 'Red Bull', were transplanted within each grower-managed field along or near the edge of the field. The area of each plot was approximately $9.3 \mathrm{~m}^{2}$, usually consisting of four rows, with a total of 400 plants. In 2011, onions were transplanted from 30 April through 6 June at all sites. In 2012, onions were transplanted between 9 May and 30 May at all sites. Transplanted onions in these insecticide-free plots were protected from onion maggot (Delia antiqua [Meigen]) by dipping the lower half of each plant in a solution of spinetoram (Radiant SC, Dow AgroSciences, Indianapolis, IN) and water at a rate of $60 \mathrm{ml}$ of product per 3.81 of water. This practice only protects the onion crop from maggots early in the season and does not impact the timing of T. tabaci colonization (unpublished results), which does not begin until June (Smith et al. 2011). No foliar insecticides were applied to these plots throughout the season, thus plots were considered "insecticide-free". Insecticide drift during treatment of the commercial field was avoided by maintaining a $2 \mathrm{~m}$ buffer around the insecticide-free plot.

\section{Sampling}

To assess predator abundance (larvae or nymphs and adults) and T. tabaci abundance (larvae only), growermanaged fields and insecticide-free plots were sampled before T. tabaci colonization of onion fields (Smith et al. 2011) until harvest. Sampling in 2011 began on 31 May and continued weekly until 1 September. In 2012, sampling occurred weekly from 30 May to 20 August. Insects were sampled using both visual counts on plants and yellow sticky cards.

In grower-managed fields, 90 and 30 onion plants were randomly selected in 2011 and in 2012, respectively, and predators and $T$. tabaci were visually identified in the field, counted and recorded. Representatives of each taxon were collected and identified in the laboratory. The reduction in plants sampled per field in 2012 was determined based on 2011 results that showed no difference in mean numbers of insects per plant using either a 90- or 30-plant sample. Plants sampled in grower-managed fields were between 2 and $20 \mathrm{~m}$ from insecticide-free plots. In insecticide-free plots, 30 onion plants were randomly selected throughout the entire plot and numbers of $T$. tabaci and predators were visually counted and recorded.

Visually sampling predators occurred during a brief period each week, i.e. an hour each week. Thus, to increase the likelihood of a more accurate census of the mobile predators in the system each week, yellow sticky cards were also used to monitor predator populations $(7 \times 12 \mathrm{~cm})$ (Olson Products, Medina, OH, USA) (Schmidt et al. 2008). In 2011 and 2012, four cards and one card, respectively, were placed in the middle of each insecticide-free plot. Sticky cards were fastened to $91 \mathrm{~cm}$ tall wooden stakes using plastic, spring-loaded clamps (Woodworker's Supply, Casper, WY, USA). Cards were positioned $10-30 \mathrm{~cm}$ above the ground within the onion plant canopy and replaced weekly. T. tabaci captured on yellow sticky cards were not recorded because on-plant count data were likely a more accurate measure of estimating their abundance. Yellow sticky cards were only placed in insecticide-free plots because it was assumed that the mobile predators would be similar across both types of management plots within a field site.

\section{Statistical analyses}

Climate differed substantially in 2011 and 2012, so data were analyzed separately by year. In 2011, the spring was cool and wet, which delayed planting in all onion growing regions in New York. In contrast, spring in 2012 was mild, which allowed for earlier than normal planting. Additionally, the 2012 growing season was attenuated by drought and the onion crop matured earlier than usual.

Average T. tabaci abundances in large-scale and small-scale systems were analyzed using a $t$ test at $P<0.05$ in JMP Pro 10 (SAS Institute Inc., 2012). Means for grower-managed fields and insecticide-free plots were calculated by averaging $T$. tabaci per plant within each week and site, then averaging across weeks.

To illustrate relative population patterns through time in each cropping system, mean predators per plant and mean $T$. tabaci per plant were illustrated $( \pm \mathrm{SE})$ on a weekly basis for the entire season. Sample sizes were not large enough to conduct time-series regression to analytically examine time lags or synchrony. 
Table 1 Season mean abundance of Thrips tabaci per onion plant $( \pm \mathrm{SE})$ in grower-managed fields and insecticide-free plots within these fields grown within either a large-scale or small-scale cropping system in 2011 and 2012 in New York (2011: $\mathrm{n}=4$ sites; 2012: $\mathrm{n}=6$ sites)

\begin{tabular}{llrr}
\hline Year & Management type & \multicolumn{2}{l}{ Cropping system } \\
\cline { 3 - 4 } & & Large-scale & \multicolumn{1}{c}{ Small-scale } \\
\hline \multirow{2}{*}{2011} & Grower-managed field & $5.5 \pm 1.6$ & $10.1 \pm 2.6$ \\
& Insecticide-free plot & $12.0 \pm 5.0$ & $9.7 \pm 2.2$ \\
2012 & Grower-managed field & $3.4 \pm 1.1$ & $14.5 \pm 5.6$ \\
& Insecticide-free plot & $21.3 \pm 2.7$ & $10.4 \pm 5.2$ \\
\hline
\end{tabular}

None of the comparisons of T. tabaci abundance significantly differed between cropping systems (all $P>0.05$ )

A generalized linear model was used to estimate the effects of two types of onion production systems (system), T. tabaci abundance (T. tabaci) and their interaction (system $\times T$. tabaci) on mean predator abundance using the GENMOD procedure in SAS v. 9.3 (SAS Institute Inc, 2011). Because insect counts were overdispersed, data were modeled using a negative binomial distribution. Field site was included in the model as a categorical variable to account for repeated measures, within subjects, specifying a type-I autoregressive covariance structure. Separate models were conducted for all predator datasets: on-plant counts in grower-managed fields, on-plant counts in insecticide-free plots, and yellow sticky cards in insecticide-free plots.

Predator abundance in each taxonomic group was low and precluded robust comparisons. Thus, for all data analyses pertaining to predator counts, total numbers of predators rather than each taxonomic group of predators were analyzed.

\section{Results}

Abundance of T. tabaci in onion systems

Infestations of T. tabaci reached economically damaging levels in all fields in both years: densities exceeded an average of 2.2 thrips per leaf (Fournier et al. 1995; Nault and Shelton 2010). In growermanaged onion fields, there were nearly two to five times fewer T. tabaci in large-scale systems than in small-scale systems in 2011 and 2012, respectively (Table 1), but these difference were not statistically significant (2011: $t_{6}=-1.516, P=0.180 ; 2012$ : $\left.t_{10}=-1.939, P=0.081\right)$. In insecticide-free onion plots, T. tabaci abundance in large-scale and smallscale systems were similar in 2011, but were twice as high in large-scale systems in 2012 (Table 1). However, none of the differences were statistically significant $\quad$ (2011: $\quad t_{6}=0.413, \quad P=0.694 ; \quad 2012$ : $\left.t_{10}=1.866, P=0.101\right)$.

Predator identity and abundance on onion plants

In 2011 and 2012, predator taxa encountered in largescale and small-scale production systems from onplant counts and sticky cards included eight species representing seven genera and five families: Aeolothrips fasciatus (L.) (Aeolothripidae) (adults only), Aeolothrips albicinctus Haliday (Aeolothripidae) (adults only), Toxomerus marginatus (Say) (Syrphidae) (larvae and adults), Sphaerophoria pyrrhina Bigot (Syrphidae) (larvae and adults), Orius insidiosus (Say) (Anthocoridae) (nymphs and adults), Coleomegilla maculata De Geer (Coccinellidae) (nymphs and adults), Hippodamia variegata (Goeze) (Coccinellidae) (nymphs and adults) and lacewings (Chrysopidae) (nymphs only). All of these taxonomic groups and their indicated life stages were observed feeding on T. tabaci larvae in onion fields. All predator life stages listed above were sampled during on-plant counts, but only adults were sampled from yellow sticky cards. Mean predator abundance from on-plant counts in the different cropping systems in growermanaged fields and insecticide-free plots are included in Table 4, Appendix 1.

Seasonal dynamics of predators and thrips on onion plants

Seasonal population dynamics of predators and $T$. tabaci were generally similar in both production systems during the season, regardless of whether data were collected from grower-managed fields or insecticide-free plots (data not shown for insecticide-free plots). Results from grower-managed fields are illustrated in Fig. 1a-d. Predator populations tended to mirror T. tabaci populations during the entire season in small-scale systems (Fig. 1b and d) and during several periods of the season in large-scale systems (Fig. 1a and c). Exceptions included predator activity early in the season in large-scale systems in 2011 (Fig. 1a) and 
Fig. 1 Population dynamics of weekly average ( \pm SE) predator abundance and T. tabaci per plant in grower-managed fields through the season in largescale systems a in 2011 $(n=4), \mathbf{c}$ in $2012(n=6)$ and in small-scale systems b in $2011(\mathrm{n}=4)$ and d $2012(\mathrm{n}=6)$. Population dynamics in insecticide-free plots were similar to growermanaged fields and therefore not illustrated. In 2011, weeks ranged from 31 May (1) to 25 August (12); in 2012, weeks ranged from 30 May (1) to 13 August (11) (a) Large-scale

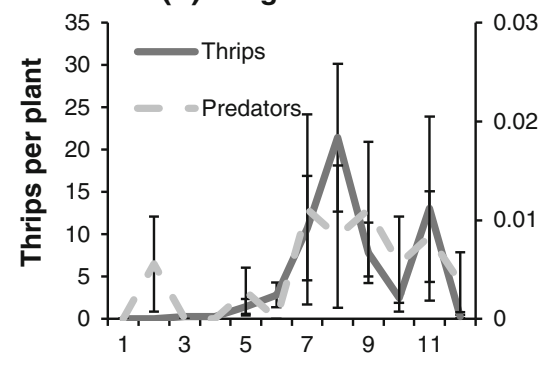

(c) Large-scale

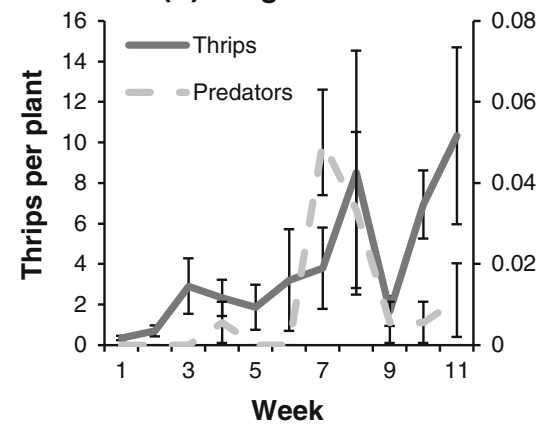

2011

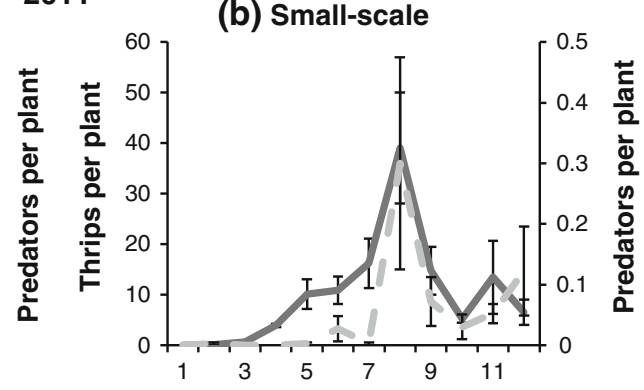

2012

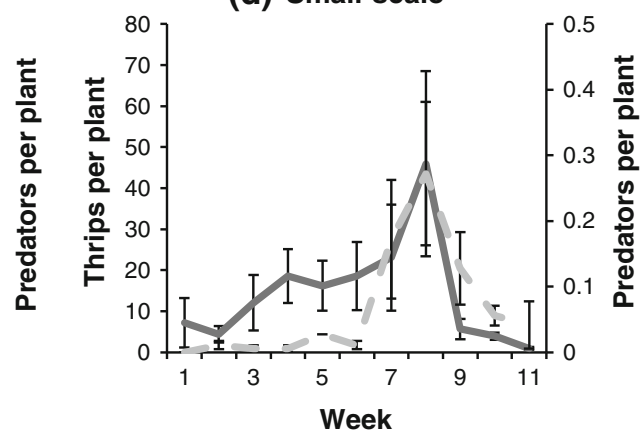

Table 2 Statistics from the generalized linear model used to analyze insect predator on-plant counts in grower-managed onion fields and in insecticide-free plots within large-scale and small-scale cropping systems in New York in 2011 and 2012

\begin{tabular}{|c|c|c|c|c|c|c|c|c|}
\hline \multirow[t]{3}{*}{ Effect } & \multicolumn{4}{|c|}{ Grower-managed fields } & \multicolumn{4}{|c|}{ Insecticide-free Plots } \\
\hline & \multicolumn{2}{|l|}{2011} & \multicolumn{2}{|l|}{2012} & \multicolumn{2}{|l|}{2011} & \multicolumn{2}{|l|}{2012} \\
\hline & Est. \pm SE & $P$-value & Est. \pm SE & $P$-value & Est. \pm SE & $P$-value & Est. \pm SE & $P$-value \\
\hline System & $1.86 \pm 0.63$ & 0.003 & $1.94 \pm 0.43$ & $<0.001$ & $-0.56 \pm 0.62$ & 0.371 & $1.24 \pm 0.40$ & 0.002 \\
\hline T. tabaci & $0.03 \pm 0.01$ & 0.015 & $0.07 \pm 0.04$ & 0.093 & $0.01 \pm 0.002$ & $<0.001$ & $0.02 \pm 0.004$ & $<0.001$ \\
\hline System $\times T$. tabaci & $0.02 \pm 0.02$ & 0.238 & $-0.05 \pm-0.13$ & 0.217 & $0.03 \pm 0.01$ & $<0.001$ & $0.01 \pm 0.01$ & 0.390 \\
\hline
\end{tabular}

System is cropping system (large scale or small scale) and T. tabaci refers to thrips abundance on onion plants. Parameter estimates (Est.) \pm standard errors (SE), and $P$-values for the $\mathrm{Z}$ test, are included for all data sets. $P$-values in bold type were considered significant $P<0.05$

an earlier peak of predators than peak of thrips abundance in large-scale systems in 2012 (Fig. 1c). In 2011, C. maculata larvae and adults were present on onion plants in large-scale systems very early in the season, despite the absence of $T$. tabaci on onion plants.

Comparison of predator abundance between onion production systems

Predator abundance was higher in small-scale systems than large-scale systems in all datasets (Table 2, 3;
Fig. 2), except for on-plant counts in insecticide-free plots in 2011. T. tabaci abundance significantly predicted predator abundance in three of the six data sets (Table 2). The interaction term T. tabaci abundance $\times$ cropping system was significant only for onplant counts in insecticide-free plots in 2011 (Table 2).

Predator abundance on onion plants in growermanaged fields in small-scale systems was significantly higher than those in large-scale systems in both 2011 (Fig. 2a) $(P=0.003)$ and 2012 (Fig. 2b) $(P<0.001)$. T. tabaci abundance also significantly 
Table 3 Statistics from the generalized linear model used to analyze insect predator counts on yellow sticky traps in insecticide-free plots within large-scale and small-scale cropping systems in New York in 2011 and 2012

\begin{tabular}{llllll}
\hline Effect & 2011 & & & 2012 & \\
\cline { 2 - 3 } \cline { 5 - 6 } & Est. \pm SE & $P$-value & & Est. \pm SE & $P$-value \\
\hline System & $0.51 \pm 0.25$ & $\mathbf{0 . 0 4 2}$ & & $0.54 \pm 0.24$ & $\mathbf{0 . 0 2 4}$ \\
T. tabaci & $0.003 \pm 0.001$ & 0.070 & & $0.01 \pm 0.01$ & 0.182 \\
System $\times$ & $-0.002 \pm 0.01$ & 0.774 & & $-0.01 \pm 0.01$ & 0.345 \\
T. tabaci & & & &
\end{tabular}

System is cropping system (large scale or small scale) and $T$. tabaci refers to thrips abundance on onion plants. Parameter estimates (Est.) \pm standard errors (SE), and $P$-values for the $\mathrm{Z}$ test, are included for all data sets. $P$-values in bold type were considered significant $P<0.05$

positively predicted predator abundance in 2011 (Fig. 3a) $(P=0.015)$ for on-plant counts in growermanaged fields.

Predator abundance on onion plants in insecticide-free plots in small-scale systems was higher than in large-scale systems in both years, but the differences were only significant in 2012 (Table 2; Fig. 2c) $(P=0.002)$. In 2011, $T$. tabaci abundance on onion plants in insecticide-free plots was significantly positively related to predator abundance (Table 2) $(P<0.001)$. The interaction term cropping system $\times T$. tabaci abundance also significantly predicted predator abundance from on-plant counts in insecticide-free plots in 2011 (Table 2; Fig. 3b) $(P<0.001)$. The relationship between predator abundance and T. tabaci abundance was positive in both large-scale $\left(\mathrm{y}=0.10 \mathrm{x}-0.30, \mathrm{R}^{2}=0.90\right)$ and smallscale systems $\left(y=0.05 x+0.38, R^{2}=0.07\right)$, but the relationship was stronger in large-scale systems. In 2012, there was a significant positive relationship between predator abundance and T. tabaci abundance in insecticide-free plots $(P<0.001)$ (Table 2$)$. Because of the multivariate model used with the negative binomial distribution, we were unable to illustrate this as a univariate relationship.

Predator abundance per yellow sticky card in insecticide-free onion plots in small-scale systems was significantly higher than those in large-scale systems (Table 3). Type of cropping system significantly predicted predator abundance on yellow sticky cards in both 2011 (Fig. 4a) $(P=0.042)$ and 2012 (Fig. 4b) $(P=0.024)$.

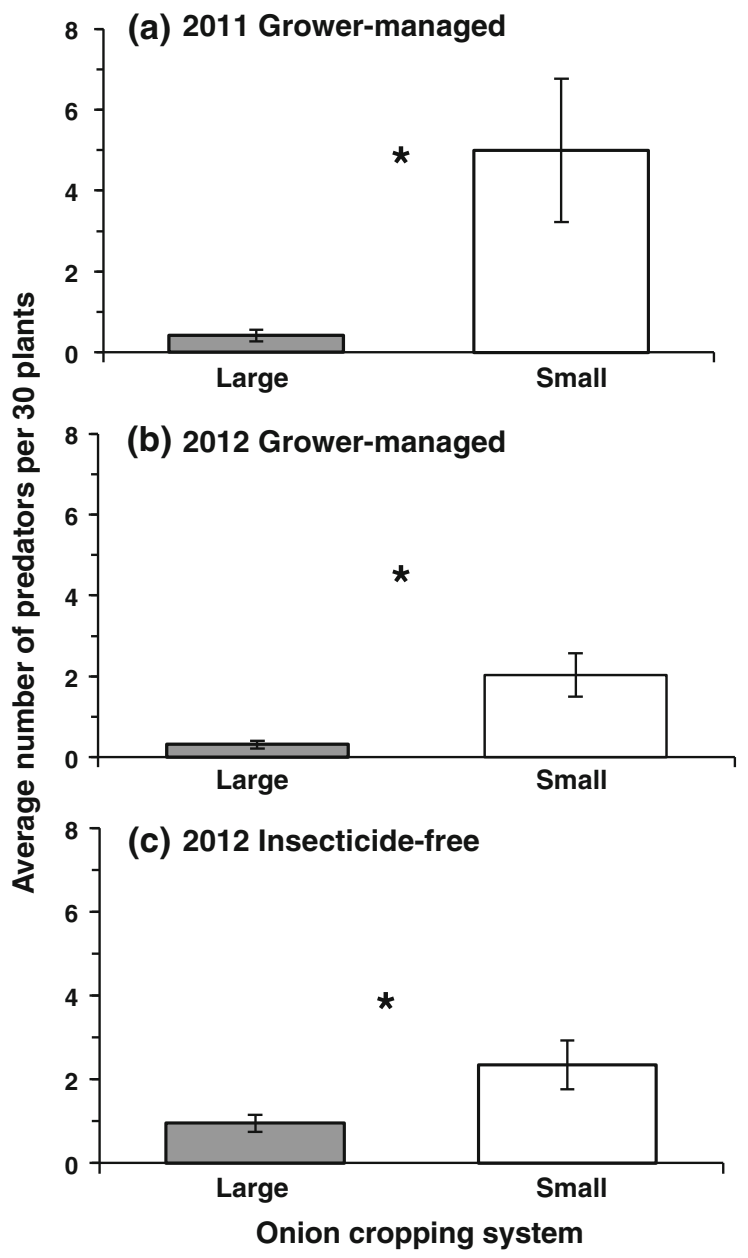

Fig. 2 Season average number of insect predators $( \pm$ SE) in grower-managed onion fields in large-scale and small-scale production systems a in 2011, b 2012, and c insecticide-free onion plots in 2012. The asterisk (*) indicates that averages differed significantly at $P<0.05$ (PROC GENMOD; $\mathrm{n}=4$ in $2011, \mathrm{n}=6$ in 2012)

\section{Discussion}

The two types of onion cropping systems in New York differed in terms of farm scale, field size, cultural and pest management practices, and diversity of surrounding vegetation. Our results indicated that predator abundance also differed between these onion production systems. Predator abundance was higher in the small-scale production system compared with the large-scale system. One explanation for these results is that $T$. tabaci densities tended to be higher in commercial onion fields in the small-scale production system than in the large-scale system, and predator 


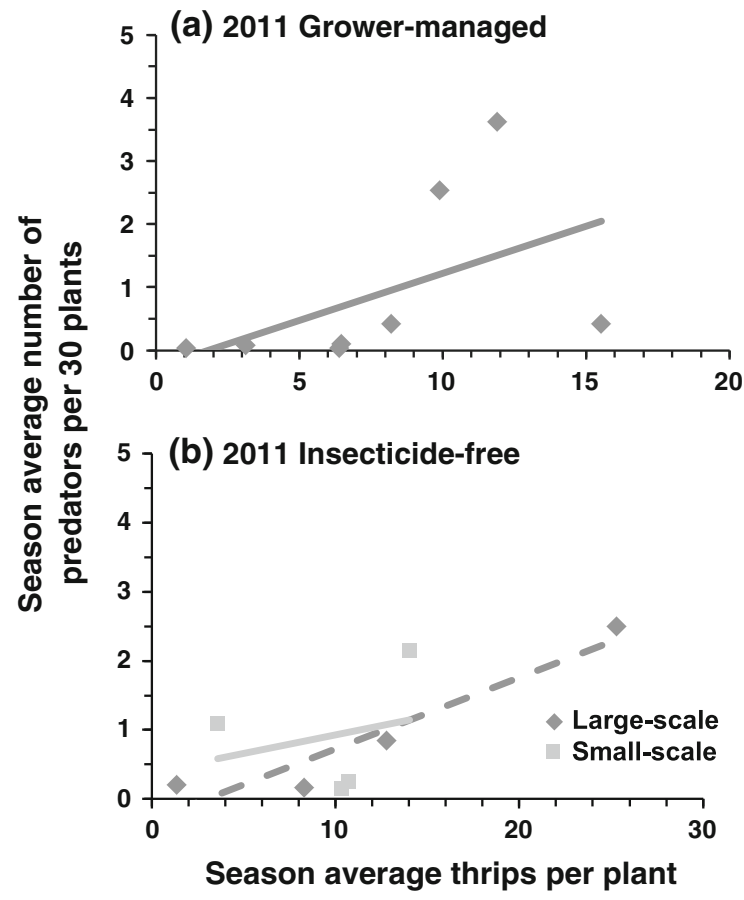

Fig. 3 Relationship between a season average number of insect predators and season average number of $T$. tabaci larvae in all grower-managed onion fields in 2011 ( $\mathrm{y}=0.15 \mathrm{x}-0.27$, $\left.\mathrm{R}^{2}=0.25, P=0.015\right)$, and $\mathbf{b}$ season average number of insect predators and season average number of $T$. tabaci in insecticidefree onion plantings situated within either a large-scale $\left(y=0.10 x-0.30, R^{2}=0.90\right)$ or small-scale onion production system in $2011\left(\mathrm{y}=0.05 \mathrm{x}+0.38, \mathrm{R}^{2}=0.07\right)$

abundance was positively predicted by thrips abundance. Thus, higher predator abundance in commercial onion fields grown in small-scale production systems may have been simply attributed to more $T$. tabaci prey. Another explanation for these results is that onion fields in small-scale production systems were treated less with insecticides compared with those in large-scale systems, potentially conserving predator populations. A third possible explanation for these results is that there was greater habitat diversification and more potential resources for predators in onion fields grown in small-scale production systems than in monocultures, a phenomenon that has been reported previously (Bianchi et al. 2006; ChaplinKramer et al. 2011).

The predator complex in both large-scale and small-scale onion production systems included eight species, representing seven genera and five families. The most commonly encountered predator on plants was adult Aeolothrips fasciatus. Adult Orius

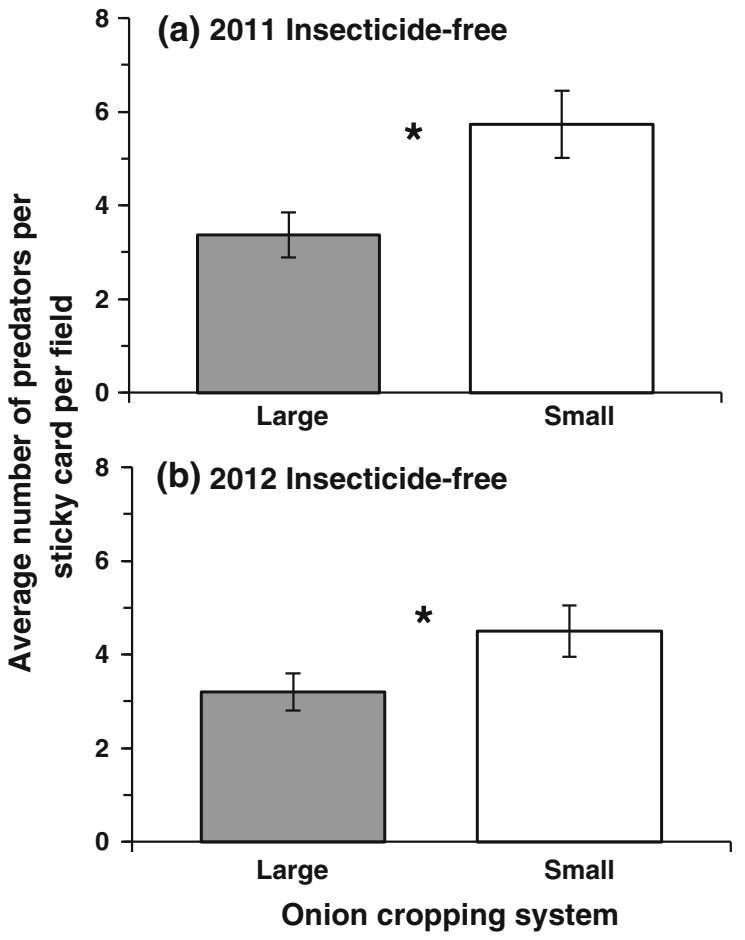

Fig. 4 Season average number of insect predators ( \pm SE) captured on yellow sticky cards located in insecticide-free onion plantings situated within either a large-scale or a small-scale onion production system a 2011 and b 2012. The asterisk (*) indicates averages were significantly different at $P<0.05$ (PROC GENMOD; $\mathrm{n}=4$ in 2011 and $\mathrm{n}=6$ in 2012)

insidiosus and larval Syrphidae also were frequently encountered. Results were consistent with those that observed predators of $T$. tabaci in non-onion cropping systems such as anthocorid bugs (Anthocoridae), lacewing larvae (Neuroptera), ladybird beetles (Coccinellidae), hoverfly larvae (Syrphidae), and predatory thrips (Aeolothripidae) (Kirk 1997b; Sabelis and van Rijn 1997). The same predator species were present in both large-scale and small-scale systems. While identifying predators of $T$. tabaci was the focus of this study, Ceranisus spp. (Hymenoptera: Eulophidae) have been reported as successful parasitoids of $T$. tabaci (Loomans and van Lenteren 1995; Loomans 2006). However, few of these parasitoids have been collected in the continental USA from $T$. tabaci hosts.

T. tabaci abundance positively predicted predator abundance across systems and management types. In particular, in large-scale systems in 2011, the relationship between predator abundance and T. tabaci 
abundance was strongly positive $\left(\mathrm{R}^{2}=0.90\right)$, indicating that, especially in these systems, predators were responding to T. tabaci abundance. Population dynamics of predators and T. tabaci throughout the season also indicated that predators and T. tabaci abundance was correlated through time. This study provides evidence of an association between predators and $T$. tabaci, suggesting that future research might consider the effects of predators on T. tabaci as a management tool.

In large-scale onion production systems in New York, other than $T$. tabaci there are relatively few resources available to insect predators during most of the onion crop production period and perhaps few resources before and after onions are grown as well. In small-scale systems, predators had access to resources in proximity to thrips-infested onion plants such as other arthropods, pollen, and shade from the surrounding vegetation before, during and after onions were grown. In small-scale systems, these other resources may help sustain higher predator populations throughout the season compared with populations that occur in large-scale systems (Polis and Strong 1996).

High abundance of C. maculata larvae and adults in onion fields in large-scale systems in May 2011 occurred when $T$. tabaci populations were low to absent. Barley is typically co-planted alongside onion seedlings and killed with a selective herbicide in late May to early June when onion seedlings reach the flagleaf stage. In mid to late May, vegetative-stage barley plants might be colonized by $T$. tabaci or other arthropods that are utilized by $C$. maculata. Research is needed to explore the possibility for barley to enhance the predator complex in large-scale onion cropping systems.

Minimizing the level of disturbance (e.g., limited insecticide use) in an agricultural system is important for the successful implementation of biological control (Landis et al. 2000; Gurr et al. 2003; Barbosa 1998). Yet, insecticide use will likely continue to be a significant component of onion thrips management in onion fields. If chemicals are used judiciously and applied appropriately, predators may be conserved (Mautino et al. 2012). Furthermore, selective insecticides may be compatible with biological control organisms such as predators and parasitoids. While varying levels of selective insecticide compatibility with some predators has been shown in onion and other cropping systems (Landis et al. 2000; Musser and Shelton 2003; Mahmoud and Osman 2007; Kraiss and Cullen 2008; Biondi et al. 2012), the extent to which selective insecticides affect suites of predators has yet to be determined.

Advancements have been made in managing $T$. tabaci in onion over the last several years by reducing the frequency of insecticide applications and the use of broad-spectrum insecticides. Agricultural systems typically lack appropriate populations of natural enemies, and the native complex is likely insufficient for T. tabaci control in their current state (Parrella and Lewis 1997). Diversification strategies in onion agroecosystems could foster the development of natural enemy populations, which could contribute to future management strategies of $T$. tabaci populations. While we did not examine diversification beyond the immediate agroecosystem, other studies have indicated positive predator population responses to heterogeneous landscapes composed of crop and non-crop habitats (Bianchi et al. 2006; Chaplin-Kramer et al. 2011). The effect of increased predator populations on pest populations, and ultimately the effect on crop yield, is worthy of future research and exploration, especially in the landscape context.

Acknowledgments We thank J. Nyrop, A. Shelton, and J. Thaler for their input and guidance throughout this project. Advice from J. Barry and the Cornell Statistics Center was invaluable. Two anonymous reviewers and A. Janssen provided constructive criticism. We appreciate the vegetable growers permitting us to conduct research on their farms and our summer research assistants. This research was supported by Cornell University's Department of Entomology, Federal Formula Funds Initiative Program, and USDA/NIFA Specialty Crops Research Initiative.

Open Access This article is distributed under the terms of the Creative Commons Attribution License which permits any use, distribution, and reproduction in any medium, provided the original author(s) and the source are credited.

\section{Appendix 1}

See Table 4. 
Table 4 Mean abundance of insect predators ( \pm SE) per site (= 30 onion plants) per week in grower-managed fields and insecticide-free plots within these fields grown within large-

\begin{tabular}{|c|c|c|c|c|c|c|c|}
\hline \multirow[t]{2}{*}{ Year } & \multirow[t]{2}{*}{ Family } & \multicolumn{2}{|c|}{$\begin{array}{l}\text { Grower-managed (mean } \pm \text { SE } \\
\text { (total count)) }\end{array}$} & \multicolumn{2}{|c|}{$\begin{array}{l}\text { Insecticide-free (mean } \pm S E \\
(\text { total count)) }\end{array}$} & \multicolumn{2}{|c|}{$\begin{array}{l}\text { Sticky cards (mean } \pm \mathrm{SE} \\
\text { (total count)) }\end{array}$} \\
\hline & & Large-scale & Small-scale & Large-scale & Small-scale & Large-scale & Small-scale \\
\hline \multirow[t]{6}{*}{2011} & Aeolothripidae & $\begin{array}{l}0.06 \pm 0.04 \\
\quad(3)\end{array}$ & $\begin{array}{l}3.12 \pm 1.17 \\
\quad(159)\end{array}$ & $\begin{array}{l}0.06 \pm 0.06 \\
\quad(3)\end{array}$ & $\begin{array}{l}0.84 \pm 0.21 \\
\quad(52)\end{array}$ & $\begin{array}{l}0.18 \pm 0.07 \\
\quad(9.25)\end{array}$ & $\begin{array}{l}0.35 \pm 0.17 \\
\quad(17.5)\end{array}$ \\
\hline & Syrphidae & $\begin{array}{l}0.23 \pm 0.11 \\
\quad(11)\end{array}$ & $\begin{array}{l}0.73 \pm 0.31 \\
\quad(37)\end{array}$ & $\begin{array}{l}0.11 \\
(5)\end{array}$ & $\begin{array}{l}0.10 \pm 0.04 \\
(6)\end{array}$ & $\begin{array}{l}0.25 \pm 0.06 \\
(12.5)\end{array}$ & $\begin{array}{c}0.49 \pm 0.24 \\
(26.5)\end{array}$ \\
\hline & Chrysopidae & $\begin{array}{l}0.08 \pm 0.05 \\
\quad(4)\end{array}$ & $\begin{array}{l}0.10 \pm 0.06 \\
(5)\end{array}$ & $0 \pm 0(0)$ & $0 \pm 0(0)$ & $\begin{array}{l}0.02 \pm 0.02 \\
\quad(1)\end{array}$ & $\begin{array}{l}0.02 \pm 0.02 \\
\text { (1) }\end{array}$ \\
\hline & Anthocoridae & $0 \pm 0(0)$ & $\begin{array}{l}0.77 \pm 0.28 \\
\quad(39)\end{array}$ & $0 \pm 0(0)$ & $\begin{array}{l}0.18 \pm 0.05 \\
\quad(11)\end{array}$ & $\begin{array}{l}0.88 \pm 0.40 \\
(43.75)\end{array}$ & $\begin{array}{l}3.15 \pm 0.39 \\
\quad(166)\end{array}$ \\
\hline & Coccinellidae & $\begin{array}{l}0.02 \pm 0.02 \\
\quad(1)\end{array}$ & $\begin{array}{l}0.20 \pm 0.09 \\
\quad(10)\end{array}$ & $\begin{array}{l}0.30 \pm 0.11 \\
\quad(14)\end{array}$ & $\begin{array}{l}0.03 \pm 0.02 \\
\quad(2)\end{array}$ & $\begin{array}{l}2.15 \pm 0.67 \\
\quad(112)\end{array}$ & $\begin{array}{l}1.36 \pm 0.38 \\
\quad(71)\end{array}$ \\
\hline & Total & $\begin{array}{l}0.39 \pm 0.14 \\
(19)\end{array}$ & $\begin{array}{l}4.90 \pm 1.74 \\
(250)\end{array}$ & $\begin{array}{l}0.47 \pm 0.14 \\
\quad(22)\end{array}$ & $\begin{array}{l}1.15 \pm 0.24 \\
\quad(71)\end{array}$ & $\begin{array}{c}3.48 \pm 0.91 \\
(178.5)\end{array}$ & $\begin{array}{l}5.37 \pm 0.51 \\
(282)\end{array}$ \\
\hline \multirow[t]{6}{*}{2012} & Aeolothripidae & $\begin{array}{l}0.08 \pm 0.03 \\
\quad(5)\end{array}$ & $\begin{array}{l}1.27 \pm 040 \\
\quad(84)\end{array}$ & $\begin{array}{l}0.65 \pm 0.17 \\
\quad(40)\end{array}$ & $\begin{array}{l}1.79 \pm 0.51 \\
\quad(118)\end{array}$ & $\begin{array}{l}0.28 \pm 0.08 \\
\quad(16)\end{array}$ & $\begin{array}{l}1.74 \pm 0.45 \\
\quad(110)\end{array}$ \\
\hline & Syrphidae & $\begin{array}{l}0.18 \pm 0.09 \\
\quad(11)\end{array}$ & $\begin{array}{l}0.52 \pm 0.22 \\
\quad(34)\end{array}$ & $\begin{array}{l}0.03 \pm 0.02 \\
\quad(2)\end{array}$ & $\begin{array}{l}0.32 \pm 0.14 \\
\quad(21)\end{array}$ & $\begin{array}{l}0.49 \pm 0.17 \\
\quad(28)\end{array}$ & $\begin{array}{l}0.45 \pm 0.33 \\
\quad(25)\end{array}$ \\
\hline & Chrysopidae & $\begin{array}{l}0.03 \pm 0.02 \\
\quad(2)\end{array}$ & $\begin{array}{l}0.17 \pm 0.06 \\
\quad(11)\end{array}$ & $\begin{array}{l}0.11 \pm 0.05 \\
\quad(7)\end{array}$ & $\begin{array}{l}0.09 \pm 0.06 \\
\quad(6)\end{array}$ & $\begin{array}{l}0.14 \pm 0.05 \\
\quad(8)\end{array}$ & $\begin{array}{l}0.03 \pm 0.02 \\
\quad(2)\end{array}$ \\
\hline & Anthocoridae & $\begin{array}{l}0.02 \pm 0.02 \\
\quad(1)\end{array}$ & $\begin{array}{l}0.08 \pm 0.05 \\
\quad(5)\end{array}$ & $\begin{array}{l}0.05 \pm 0.04 \\
\quad(3)\end{array}$ & $\begin{array}{l}0.02 \pm 0.02 \\
\quad(1)\end{array}$ & $\begin{array}{l}1.45 \pm 0.39 \\
\quad(83)\end{array}$ & $\begin{array}{l}1.38 \pm 0.37 \\
\quad(84)\end{array}$ \\
\hline & Coccinellidae & $\begin{array}{l}0.16 \pm 0.16 \\
\quad(1)\end{array}$ & $\begin{array}{l}0.21 \pm 0.08 \\
\quad(14)\end{array}$ & $\begin{array}{l}0.11 \pm 0.05 \\
\quad(7)\end{array}$ & $\begin{array}{l}0.11 \pm 0.05 \\
\quad(7)\end{array}$ & $\begin{array}{l}0.85 \pm 0.17 \\
\quad(48)\end{array}$ & $\begin{array}{l}1.04 \pm 0.46 \\
(61)\end{array}$ \\
\hline & Total & $\begin{array}{l}0.32 \pm 0.10 \\
\quad(20)\end{array}$ & $\begin{array}{l}2.24 \pm 0.58 \\
(148)\end{array}$ & $\begin{array}{l}0.95 \pm 0.21 \\
\quad(59)\end{array}$ & $\begin{array}{l}2.32 \pm 0.58 \\
(150)\end{array}$ & $\begin{array}{l}3.20 \pm 0.52 \\
\quad(183)\end{array}$ & $\begin{array}{c}4.63 \pm 0.63 \\
(282)\end{array}$ \\
\hline
\end{tabular}

A list of insect predator species is presented in the text

\section{References}

Altieri M, Nicholls CA (2001) Ecological impacts of modern agriculture in the United States and Latin America. In: Solbrig OT, Paarlberg R, Di Castri (eds) Globalization and the rural environment. Harvard University Press, USA, pp 121-135

Barbosa PA (1998) Conservation biological control. Academic Press, USA

Bianchi F, Booij C, Tscharntke T (2006) Sustainable pest regulation in agricultural landscapes: a review on landscape composition, biodiversity and natural pest control. Proc R Soc B 273:1715-1727

Biondi A, Desneux N, Siscaro G, Zappalà L (2012) Using organic-certified rather than synthetic pesticides may not be safer for biological control agents: selectivity and side effects of 14 pesticides on the predator Orius laevigatus. Chemosphere 87:803-812

Chaplin-Kramer R, O'Rourke ME, Blitzer EJ, Kremen C (2011) A meta-analysis of crop pest and natural enemy response to landscape complexity. Ecol Lett 14:922-932 scale or small-scale cropping systems in 2011 and 2012 in New York (2011: $\mathrm{n}=4$ sites; 2012: $\mathrm{n}=6$ sites) 
axyridis (Coleoptera: Coccinellidae). J Econ Entomol 101:391-398

Landis DA, Wratten SD, Gurr GM (2000) Habitat management to conserve natural enemies of arthropod pests in agriculture. Annu Rev Entomol 45:175-201

Loomans AJ (2006) Exploration for hymenopterous parasitoids of thrips. Bull Insectol 59:69-83

Loomans A, van Lenteren J (1995) Biological control of thrips pests: a review on thrips parasitoids. Wageningen Agric Univ, The Netherlands, pp 95:89-201

Mahmoud MF, Osman MA (2007) Relative toxicity of some biorational insecticides to second instar larvae and adults of onion thrips (Thrips tabaci Lind.) and their predator Orius albidipennis under laboratory and field conditions. J Plant Prot Res 47:391-400

Mautino GC, Bosco L, Tavella L (2012) Integrated management of Thrips tabaci (Thysanoptera: Thripidae) on onion in north-western Italy: basic approaches for supervised control. Pest Manag Sci 68:185-193

Mound LA (2005) Thysanoptera: diversity and interactions. Annu Rev Entomol 50:247-269

Musser FR, Shelton AM (2003) Bt sweet corn and selective insecticides: impacts on pests and predators. J Econ Entomol 96:71-80

Nault BA, Shelton AM (2010) Impact of insecticide efficacy on developing action thresholds for pest management: a case study of onion thrips (Thysanoptera: Thripidae) on onion. J Econ Entomol 103:1315-1326

Nault BA, Hsu CL, Hoepting CA (2013) Consequences of coapplying insecticides and fungicides for managing Thrips tabaci (Thysanoptera: Thripidae) on onion. Pest Manag Sci 69:841-849

Parrella M, Lewis T (1997) Integrated pest management (IPM) in field crops. In: Lewis T (ed) Thrips as Crop Pests. Cab International, UK, pp 595-614

Polis GA, Strong DR (1996) Food web complexity and community dynamics. Am Nat 147:813-846

Reiners S, Petzoldt C (2014) Integrated crop and pest management guidelines for commercial vegetable production.
Cornell cooperative extension publication. http://vegguidelines.cce.cornell.edu/

Sabelis M, van Rijn P (1997) Predation by insects and mites. In: Lewis T (ed) Thrips as crop pests. Cab International, UK, pp 259-354

Schmidt N, O’Neal M, Dixon P (2008) Aphidophagous predators in Iowa soybean: a community comparison across multiple years and sampling methods. Ann Entomol Soc Am 101:341-350

Shelton A, Zhao J, Nault B, Plate J, Musser F, Larentzaki E (2006) Patterns of insecticide resistance in onion thrips (Thysanoptera: Thripidae) in onion fields in New York. J Econ Entomol 99:1798-1804

Smith EA, Ditommaso A, Fuchs M, Shelton A, Nault B (2011) Weed hosts for onion thrips (Thysanoptera: Thripidae) and their potential role in the epidemiology of Iris yellow spot virus in an onion ecosystem. Environ Entomol 40:194-203

Tscharntke T, Clough Y, Wanger T, Jackson L, Motzke I, Perfecto I, Vandermeer J, Whitbread A (2012) Global food security, biodiversity conservation and the future of agricultural intensification. Biol Conserv 151:53-59

Elaine J. Fok is a recent graduate of Cornell University where she obtained a M.S. degree in Entomology. Her interests span agricultural entomology and biological control to fostering the development of local food systems.

Jessica D. Petersen is a post-doctoral associate who has general expertise in landscape ecology, agricultural entomology and statistics. Her recent research has focused on pollinator ecology in vegetable cropping systems.

Brian A. Nault is a professor and applied insect ecologist who studies pests and beneficial insects in vegetable cropping systems and develops integrated pest management programs. For nearly 15 years, he has studied the ecology and management of onion thrips, Thrips tabaci, and onion maggot, Delia antiqua, in onion cropping systems. 